Review Article

\title{
Understanding Units of Measurement in Agricultural and Environmental Sciences
}

Malyan, Sandeep K. ${ }^{1}$, Kumar, Om², Ranjan, Rumesh ${ }^{2}$ and Kumar, Joni ${ }^{2}$

${ }^{1}$ Environmental Hydrology Division, National Institute Hydrology, Roorkee, Uttarakhand, India

${ }^{2}$ ICAR-Indian Agricultural Research Institute, Pusa Campus, New Delhi, India

Corresponding Author: sandeepkmalyan@gmail.com

\section{A R T I C L E I N F O}

Received: 02 June 2018 | Accepted: 21 August 2018 | Published Online: 31 December 2018

DOI: $10.31786 / 09756272.18 .9 .2 .207$

EOI: 10.11208/essence.18.9.2.207

Article is an Open Access Publication.

This work is licensed under Attribution-Non Commercial 4.0 International

(https://creativecommons.org/licenses/by/4.0/)

CThe Authors (2018). Publishing Rights @ MANU_ICMANU \& ESSENCE_IJERC.

\section{A B S T R A C T}

National and international technical agricultural and environmental sciences reports involving air, water, and soil contamination generally published numerical data in the scientific unit which were not familiar to new research scholar students. Even the use of different unit in same research area may be confusing for many of the report reader. The objective of this article is to assist people for understanding commonly used measurement units seen in many agricultural and environmental publications.

\section{K E Y W O R D S}

Environmental Science | Agricultural Science | Measurement units | Unit conversion

\section{I T A T I O N}

Malyan, Sandeep K.; Kumar, Om; Ranjan, Rumesh and Kumar, Joni (2018): Understanding Units of Measurement in Agricultural and Environmental Sciences: A Threat to Sustainable Management of Water. ESSENCE Int. J. Env. Rehab. Conserv. IX (1): 45-51. 


\section{Introduction}

Number is an arithmetical value, represented by figure, word, or symbol, for the expression of a particular quantity. One (1) is the unity of measurement (Fig. 1) and it is define as the magnitude of quantity. Globally The International System of Units (SI) is accepted for reporting the environmental, agricultural, other stream of sciences. SI is based on the meter-kilogramsecond (MKS) systems of unit and SI systems is adopted by all the developed and developing countries of the worlds including India expect three country. There is total 195 countries in the world and out of which only three country namely- United State of America, Burma, and Liberia have not adopted the SI systems of International unit measurement. US, Myanmar (formerly known as Burma), and Liberia is using the Imperial, Burmese, and United States Customary units systems respectively.

Examples of common unit of measurement are given below:

\begin{tabular}{|c|c|c|c|}
\hline The number & Name & Prefix & Symbol \\
\hline $1,000,000,000,000$ & trillion & tera & $T$ \\
\hline $1,000,000,000$ & billion & giga & G \\
\hline $1,000,000$ & million & mega & M \\
\hline 1,000 & thousand & kilo & k \\
\hline 100 & hundred & hecto & h \\
\hline 10) & ten & deka & da \\
\hline 1 & \multicolumn{3}{|c|}{ Unit of measurement } \\
\hline . & tenth & deci & d \\
\hline 0.01 & hundredth & centi & c \\
\hline 0.001 & thousandth & milli & m \\
\hline 0.000001 & millionth & micro & $\mu$ \\
\hline 0.000000001 & billionth & nano & n \\
\hline 0.000000000001 & trillionth & pico & $\mathbf{p}$ \\
\hline
\end{tabular}

Fig. 1: Commonly used big and small with their prefix and symbol

Example: 1 - Whom to use in the case of mass. SI unit of mass is kilogram (two words- prefixkilo which is equal to 1000 and gram; means 1 $\mathrm{kg}$ is equal to 1000 gram). More details for using prefix and unit are given below:

\begin{tabular}{|c|c|c|}
\hline $\begin{array}{c}1 \text { dekgram }(\text { dag })= \\
10 \mathrm{~g}\end{array}$ & \multirow{6}{*}{$\begin{array}{l}1 \text { is } \\
\text { unit }\end{array}$} & $\begin{array}{c}1 \text { decigram }(\mathrm{dg})=0.1 \\
\mathrm{~g}\end{array}$ \\
\hline $\begin{array}{c}1 \text { hectogram }(\text { hg })= \\
100 \mathrm{~g}\end{array}$ & & $\begin{array}{c}1 \text { centigram }(\mathrm{cg})= \\
0.01 \mathrm{~g}\end{array}$ \\
\hline $\begin{array}{c}1 \text { kilogram }(\mathrm{kg})= \\
1,000 \mathrm{~g}\end{array}$ & & $\begin{array}{c}1 \text { milligram }(\mathrm{mg})= \\
0.001 \mathrm{~g}\end{array}$ \\
\hline $\begin{array}{c}1 \text { megagram }(\mathrm{Mg})= \\
1,000000 \mathrm{~g}\end{array}$ & & $\begin{array}{c}1 \text { microgram }(\mu \mathrm{g})= \\
0.000001 \mathrm{~g}\end{array}$ \\
\hline $\begin{array}{c}1 \text { gigagram }(\mathrm{Gg})= \\
1,000000000 \mathrm{~g}\end{array}$ & & $\begin{array}{c}1 \text { nanogram }(\mathrm{ng})= \\
0.000000001 \mathrm{~g}\end{array}$ \\
\hline $\begin{array}{l}1 \text { teragram }(\mathrm{Tg})= \\
1,000000000 \mathrm{~g}\end{array}$ & & $\begin{array}{c}1 \text { picogram }(\mathrm{pg})= \\
0.000000000001 \mathrm{~g}\end{array}$ \\
\hline
\end{tabular}

Note: kilo, mega, giga and tera are thousand times bigger of pervious value; similar milli, micro, Nano, and Pico are thousand times smaller (Source: Terrie K. Boguski, 2006).

\section{Volume}

One litre $(\mathrm{L})=1,000$ millilitre $(\mathrm{ml})=1,000$ cubic centimetres $(\mathrm{cm} 3)$

One cubic meters $(\mathrm{m} 3)=1,000 \mathrm{~L}$

\section{Commonly used conversion in water}

Concentrations of contaminates in water are generally expressed as parts per million or parts per billion (Gupta et al., 2018; Yadav et al., 2018a \& b; Spellman, 2017; Kumar et al., 2017; Kumar et al., 2016; Fewtrell and Bartram, 2001; Bhatia et al., 2015). Contaminated level in water is also reported in the term of the mass of contaminated present in per volume of water $(\mathrm{mg} / \mathrm{L}, \mu \mathrm{g} / \mathrm{L})$ (Singh et al., 2013; Sharma et al., 2012a \& b). Microgram per liter and milligram per litre may be converted from one to the other using this relationship: $1 \mathrm{mg} / \mathrm{L}=1,000 \mathrm{mg}$. Similarly, the 
other conversion can also be done and few important conversion typically used in environmental/ agricultural reports are given below:

\begin{tabular}{c}
\hline $1 \mathrm{ppm}=1 \mathrm{mg} / \mathrm{L}$ \\
\hline $1 \mathrm{ppb}=1 \mu \mathrm{g} / \mathrm{L}$ \\
$1 \mathrm{ppm}=1,000 \mathrm{ppb}$
\end{tabular}

For example: A concentration of arsenic (10 ppm) is the identical to concentration of arsenic (10 $\mathrm{mg} / \mathrm{L}$ ) and which is same to $10,000 \mathrm{ppb}$ or 10,000 $\mu \mathrm{g} / \mathrm{L}$.

In some of the environmental study, concentrations of contaminated in water may be reported as $\mathrm{g} / \mathrm{m} 3$ or $\mathrm{mg} / \mathrm{m} 3$. As descried above in volume section, one $\mathrm{m} 3$ is equal to $1,000 \mathrm{~L}$. Therefore, the unit of $\mathrm{g} / \mathrm{m} 3$ can also be converted further as follow:

$$
\begin{array}{r}
1 \mathrm{~g} / \mathrm{m} 3=\frac{1 \mathrm{~g}}{1 \mathrm{~m} 3}=\frac{1 \mathrm{~g}}{1,000 \mathrm{~L}}=\frac{1,000 \mathrm{mg}}{1,000 \mathrm{~L}} \\
=\frac{1 \mathrm{mg}}{\mathrm{L}}=\frac{1 \mathrm{mg}}{\mathrm{L}}=1 \mathrm{ppm}
\end{array}
$$

Similar the milligram per meters cubic $(\mathrm{mg} / \mathrm{m} 3)$ in water can also be converted into microgram per liter $(\mu \mathrm{g} / \mathrm{L})$ and it was equal to $\mathrm{ppb}$.

\section{Human health risk assessment due to drinking of contaminated water}

Human health risk assessment can be calculated by hazard quotient (HQ). If the HQ value is less than 0.1, it indicates no adverse effect on human health, HQ value 0.1-1.0, it indicates low hazard and potentially effect human health, HQ value 1.0-10.0, it indicate moderate hazard and have negative human health effects, and HQ value above 10.0 indicate high human effect (Nimick et al., 2004). HQ can compute by total daily intake (TDI) and chronic daily intake (CDI) according to
Kumar et al., (2017). The TDI was determined by using the following equation

$$
\mathrm{TDI}=\mathrm{CRD} \times \mathrm{XED}
$$

Where $\mathrm{CRD}=$ Water consumed per day, CED $=$ Heavy metal concentration in drinking water.

$$
\mathrm{CDI}=\mathrm{TDI} / \text { Body weight }
$$

And the HQ for the toxic metals in drinking water was calculated by the following equation given below:

$$
\mathrm{HQ}=\mathrm{CDI} / \text { References oral dose }
$$

Commonly used conversion greenhouses gases

Agriculture is potent source of greenhouses gases (GHGs) emission to atmosphere (Malyan et al., 2016a \& b; Gupta et al., 2016; IPCC, 2014; Kumar et al., 2016). Climate change is the out came of the rapid increased in atmospheric GHGs in the last few decades (Kumar et al., 2017; Kumar and Malyan, 2016; IPCC, 2014). Different agricultural activity were the sources of different GHGs such as carbon dioxide (CO2), methane (CH4), and nitrous oxide (N2O) (Fagodiya et al., 2017; Malyan et al., 2016c; Pathak et al., 2016; Bhattacharyya et al., 2018). The impact of this different GHGs in atmosphere is measurement in the term of global warming potential (GWP). GWP is define as the quantification of the averaged relative radiative forcing impact of particular GHGs as compared to $\mathrm{CO} 2$ which is set as unit or one by Intergovernmental Panel on Climate Change (IPCC). Agriculture system, emits $\mathrm{CH} 4$ and $\mathrm{N} 2 \mathrm{O}$ which are consider as potent GHGs due to their 28 and 298 times GWP as compared to CO2 respectively (IPCC, 2014).

Some important facts in GHGs

\begin{tabular}{l} 
GWP of $\mathrm{CO}_{2}=1$ (Unit) \\
GWP of $\mathrm{CH}_{4}=28$ \\
\hline GWP of $\mathrm{N}_{2} \mathrm{O}=298$
\end{tabular}


The GHGs emission from agricultural soils is measured in respect with per unit surface area within a specific time (For more details of equation, Pathak et al., 2005). Agricultural and Environmental Sciences reports published from different region which have dissimilar unit, which make its complex for new readers. GHGs emission in term $\mathrm{CO} 2$ equivalent is globally accepted and assist the reader. Some of the commonly reported unit in GHGs studies and their method of conversion to $\mathrm{CO} 2$ equivalent are given below with example:

Let assumed, the total cumulative GHGs emission from one hectare field per season were $43 \mathrm{~kg} \mathrm{CH} 4$ $\mathrm{ha}^{-1}$, $2.6 \mathrm{~kg} \mathrm{~N} \mathrm{~N}_{2} \mathrm{O}$ ha-1 and $10 \mathrm{~kg} \mathrm{CO}$ ha-1. Than GWP in terms of $\mathrm{CO}_{2}$ equivalent will be calculated as follows:

GWP $\left(\mathrm{CO}_{2}\right.$ equivalent ha heason $\left.^{-1}\right)=$ [cumulative $\mathrm{CH}_{4}$ emission * GWP of $\mathrm{CH}_{4}$ ] + [cumulative $\mathrm{N}_{2} \mathrm{O}$ emission * GWP of $\mathrm{N} 2 \mathrm{O}$ ] + [cumulative $\mathrm{CO}_{2}$ emission * GWP of $\mathrm{CO} 2$ ]

Hence,

GWP $\left(\mathrm{CO}_{2}\right.$ equivalent ha ${ }^{-1}$ season $\left.^{-1}\right)=[43 * 28]$ $+[2.6 * 298]+[10 * 1]$

$$
=[1204]+[774.8=775]+[10]
$$

GWP $\left(\mathrm{CO}_{2}\right.$ equivalent ha-1 season-1 $)=1989$

\section{Some other important conversion in GHGs research area}

Carbon equivalents emissions (CEE), carbon efficiency ratio (CER), greenhouses gas intensity (GHGI)

$$
\mathrm{CEE}=\mathrm{GWP} * 12 / 44
$$

For example: Let us assumed the GWP of rice crop is 1300 than is CEE will be

$\mathrm{CEE}=1300 * 12 / 44=354.55$

$\mathrm{CER}=$ Grain yield $(\mathrm{kg} / \mathrm{ha})$ of the crop in terms of $\mathrm{C} / \mathrm{CEE}$
Some of the important conversion in the field of

\begin{tabular}{|c|c|c|c|}
\hline \multicolumn{2}{|c|}{ Conversion } & \multirow{2}{*}{$\begin{array}{l}\text { Factor for } \\
\text { conversion }\end{array}$} & \multirow{2}{*}{ Example } \\
\hline From & To & & \\
\hline $\mathrm{mg} / \mathrm{m}^{2}$ & $\mathrm{~kg} / \mathrm{ha}$ & $\begin{array}{l}\text { Divided by } \\
100\end{array}$ & $\begin{array}{l}10 \mathrm{mg} \mathrm{CH}_{4} / \mathrm{m}^{2} \text { will be } \\
\text { equal to } 0.1 \mathrm{~kg} \mathrm{CH} 4 \\
\text { /ha } \\
10 \mathrm{mg} / \mathrm{m} 2=\frac{10}{100} \\
=0.1 \mathrm{~kg} / \mathrm{ha}\end{array}$ \\
\hline $\mathrm{CH}_{4}-\mathrm{C}$ & $\begin{array}{l}\mathrm{kg} \\
\mathrm{CH}_{4}\end{array}$ & $\begin{array}{l}\text { Multiple by } \\
\frac{16}{12}\end{array}$ & $\begin{array}{l}10 \mathrm{~kg} \mathrm{CH}_{4}-\mathrm{C} \text { will be } \\
\text { equal to } 13.33 \mathrm{~kg} \mathrm{CH}_{4}\end{array}$ \\
\hline $\begin{array}{l}\mathrm{N}_{2} \mathrm{O}- \\
\mathrm{N}\end{array}$ & $\begin{array}{l}\mathrm{kg} \\
\mathrm{N}_{2} \mathrm{O}\end{array}$ & $\begin{array}{l}\text { Multiple by } \\
\frac{44}{28}\end{array}$ & $\begin{array}{l}10 \mathrm{~kg} \mathrm{~N} \mathrm{~N}_{2} \mathrm{O}-\mathrm{N} \text { will be } \\
\text { equal to } 15.71 \mathrm{~kg} \mathrm{~N}_{2} \mathrm{O}\end{array}$ \\
\hline $\mathrm{CO}_{2}-\mathrm{C}$ & $\begin{array}{l}\mathrm{Kg} \\
\mathrm{CO}_{2}\end{array}$ & $\begin{array}{l}\text { Multiple by } \\
\frac{44}{12}\end{array}$ & $\begin{array}{l}10 \mathrm{~kg} \mathrm{CO}_{2}-\mathrm{C} \text { will be } \\
\text { equal to } 36.67 \mathrm{~kg} \mathrm{CO}_{2}\end{array}$ \\
\hline
\end{tabular}
GHGs emission was give below:

Table 2: (Sources: IPCC, 2013; Gupta et al., 2015; 2016a \& b; Jain et al., 2016; Kumar et al., 2017)

For example: Lets assumed the grain yield of rice crop is $4000 \mathrm{~kg} / \mathrm{ha}$ and its cumulative GWP is 1300, than its CER will be,

First calculated CEE as demonstrated above, if GWP 1300 CEE will be 354.55, and the carbon content in rice $48 \%$ of total grain yield (Bhatia et al., 2010 \& 2013; Suryavanshi et al., 2013).

Therefore, Grain yield (in terms of carbon) $=$ total grain yield $* 40 / 100=4000 * 40 / 100=1600$

$\mathrm{CER}=($ Grain yield in $\mathrm{C}) / \mathrm{CEE}=1600 / 354.55=4.51$

GHGI $=$ Grain yield $/$ GWP, if we calculated GHGI of the same example it will be,

GHGI $=4000 / 1300=3.08$

Note: Unit of CEE is $\mathrm{kg} \mathrm{C}$ ha-1, CER- unit less as it is a ratio, GHGI- unit is $\mathrm{kg} \mathrm{CO} 2$-equivalent $\mathrm{kg}^{-1}$ grain yield.

\section{Acknowledgments}

This work was finically supported by National Hydrology Project (NHP) under the Purpose Driven Studies (PDS). 


\section{References}

Bhatia, A.; Kumar, A.; Das, T. K.; Singh, J.; Jain, N. and Pathak, H. (2013): Methane and nitrous oxide emissions from soils under direct seeded rice. Intl. J. Agric. Stat. Sci, 9, 729-736.

Bhatia, A.; Sasmal, S.; Jain, N.; Pathak, H.; Kumar, R. and Singh, A. (2010): Mitigating nitrous oxide emission from soil under conventional and no-tillage in wheat using nitrification inhibitors. Agric. Ecosyst. Environ, 136, 247-253.

Bhatia, A.; Singh, S. D. and Kumar, A. (2015): Heavy metal contamination of soil, irrigation water and vegetables in peri urban agricultural areas and markets of Delhi. Water Environ. Res. 87(11): 20272034.

Bhattacharyya, R.; Bhatia, A.; Das, T. K.; Lata, S.; Kumar, A.; Tomer, R.; Singh, G.; Kumar, S. and Biswas, A. K. (2018): Aggregateassociated $\mathrm{N}$ and global warming potential of conservation agriculturebased cropping of maize-wheat system in the north-western Indo-Gangetic Plains. Soil Tillage Res. 182, 66-77

Fagodiya, R. K.; Pathak, H.; Kumar, A.; Bhatia, A. and Jain, N. (2017): Global temperature change potential of nitrogen use in agriculture: A 50-year assessment. Sci. Rep. 7, 44928.

Fewtrell, L. and Bartram, J. (eds.,) (2001): Water Quality: Guidelines, Standards \& Health. IWA publishing.

Gupta, D. K.; Bhatia, A.; Das, T. K.; Singh, P.; Kumar, A.; Jain, N. and Pathak, H. (2016a): Economic analysis of different greenhouse gas mitigation technologies in rice-wheat cropping system of the Indo-
Gangetic Plains. Curr. Sci. 110(5), 867873.

Gupta, D. K.; Bhatia, A.; Kumar, A.; Das, T. K.; Jain, N.; Tomer, R.; Malyan, S. K.; Fagodiya, R. K.; Dubey, R. and Pathak, H. (2016b): Mitigation of greenhouse gas emission from rice-wheat system of the Indo-Gangetic plains: Through tillage, irrigation and fertilizer management. Agric. Ecosyst. Environ, 230, 1-9.

Gupta, N.; Yadav, K. K.; Kumar, V.; Kumar, S.; Chadd, R. and Kumar, A. (2018): Trace elements in soil-vegetable interface: Translocation, Bioaccumulation, toxicity and amelioration-A Review. Sci. Total Environ. 651(2): 2927-2942.

IPCC (2013): In: Stocker, T. F. et al. (Eds.), Climate Change 2013: The Physical Science Basis in Contribution of Working Group I to the Fifth Assessment Report of the Intergovernmental Panel on Climate Change (Cambridge and New York).

IPCC (2014): Climate Change 2014: Impacts, Adaptation, and Vulnerability Working Group II Contribution to the Fifth Assessment Report. Cambridge University Press, Cambridge, UK and New York, NY USA

Jain, N.; Arora, P.; Tomer, R.; Mishra, S. V.; Bhatia, A.; Pathak, H.; Chakraborty, D.; Kumar, V.; Dubey, D. S.; Harit, R. C. and Singh, J. P. (2016): Greenhouse gases emission from soils under major crops in Northwest India. Sci. Total Environ. 542, 551-561.

Kumar, A.; Bhatia, A.; Fagodiya, R. K.; Malyan, S. K. and Meena, B. L. (2017): Eddy Covariance Flux Tower: A Promising Technique for Greenhouse Gases 
Measurement. Adv. Plants \& Agr. Res. 7, 00263.

Kumar, A.; Sharma, M. P. and Kumar, A. (2016): Green House Gas Emissions from Hydropower Reservoirs: Policy and Challenges. Int. J. Renew. Energy Res. 6(2): 472-476.

Kumar, M.; Ramanathan, A. L.; Tripathi, R.; Farswan, S.; Kumar, D. and Bhattachrya, P. (2017): A study of trace element contamination using multivariate statistical techniques and health risk assessment in groundwater of Chhaprola Industrial Area, Gautam Buddha Nagar, Uttar Pradesh, India. Chemosphere, 166, 135-145.

Kumar, S. S. and Malyan, S. K. (2016): Nitrification Inhibitors: A Perspective Tool to Mitigate Greenhouse Gas Emissions from Rice Soils. Curr. World Environ. 11(2): 423-428.

Kumar, S. S.; Kadier, A.; Malyan, S. K.; Ahmad, A. and Bishnoi, N. R. (2017): Phytoremediation and Rhizoremediation: Uptake, Mobilization and Sequestration of Heavy Metals by Plants. In PlantMicrobe Interactions in Agro-Ecological Perspectives (pp. 367-394). Springer, Singapore.

Kumar, S. S.; Malyan, S. K.; Kumar, A. and Bishnoi, N. R. (2016): Optimization of Fenton's Oxidation by Box-Behnken Design of Response Surface Methodology for Landfill Leachate. J. Mat. Environ. Sci. 7(12): 4456-4466.

Malyan, S. K.; Kumar, A.; Kumar, J. and Kumar, S. S. (2016a): Water Management Tool in Rice to Combat two Major Environmental Issues: Global Warming and Water Scarcity, 58.
Malyan, S. K.; Bhatia, A.; Kumar, A.; Gupta, D. K.; Singh, R.; Kumar, S. S.; Tomer, R.; Kumar, O. and Jain, N. (2016b): Methane production, oxidation and mitigation: a mechanistic understanding and comprehensive evaluation of influencing factors. Sci. Total Environ. 572, 874-896.

Malyan, S. K.; Bhatia, A.; Kumar, O. and Tomer, R. (2016c): Impact of Nitrogen Fertilizers on Methane Emissions from Flooded Rice. Curr. World Environ. 11(3): 846850 .

Nimick, D. A.; Church, S. E. and Finger, S. E. (2004): Integrated Investigations of Environmental Effects of Historical Mining in the Basin and Boulder Mining Districts, Boulder River Watershed, Jefferson County, Montana. U.S. Geological Survey, Reston, Virginia.

Pathak, H.; Bhatia, A.; Prasad, S.; Singh, S.; Kumar, S.; Jain, M. C. and Kumar, U. (2002): Emission of nitrous oxide from rice-wheat systems of Indo-Gangetic plains of India. Environ. Moni. Assess. 77, 163-178.

Pathak, H.; Jain, N.; Bhatia, A.; Kumar, A. and Chatterjee, D. (2016): Improved Nitrogen Management: A key to climate change adaptation and mitigation. Indian J. Fer, 12(11): 151-162.

Sharma, A.; Kumar, A. and Dhaka, T. S. (2012a): Impact on sugar factory effluent on chlorophyll and protein contents of Cicer arietinum and Tigonella foenumgracecum. Curr. Adv. Agri Sci. 4(1): 6263.

Sharma, A.; Kumar, A. and Dhaka, T. S. (2012b): Impact of sugar factory effluent on seed germination, seedling growth of Cicer 
arietinum and Trigonella foenumgraecum. Bioinfolet 9(2): 220-221.

Singh, J.; Rawat, K. S.; Kumar, A. and Singh, A. (2013): Effect of sewage sludge and biofertilizers on physicochemical properties of alluvial soil. Biochem. Cell. Arch. 13(2): 191-202.

Spellman, F. R. (2017): The drinking water handbook. CRC Press.

Suryavanshi, P.; Singh, Y. V.; Prasanna, R.; Bhatia, A. and Shivay, Y. S. (2013): Pattern of methane emission and water productivity under different methods of rice crop establishment. Paddy Water Environ. 11, 321-329.
Terrie K. and Boguski, P. E. (2006): Understanding Units of Measurement, Environmental Science and Technology Briefs for Citizens, 2, 1-2.

Yadav, K. K.; Gupta, N.; Kumar, A.; Reece, L. M.; Singh, N.; Rezania, S. and Khan, S. A. (2018b): Mechanistic understanding and holistic approach of phytoremediation: A review on application and future prospects Ecol. Eng. 120, 274-298.

Yadav, K.; Gupta, N.; Kumar, V.; Khan, S. A. and Kumar, A. (2018a): A review of emerging adsorbents and current demand for defluoridation of water: Bright future in water sustainability Environ. Int. 111, 80108. 